\title{
Effect of bentonite and zeolite on some characteristics of acidic sandy soil and on the biomass of a testplant
}

\author{
J. KÁTAI, M. TÁLLAI, ZS. SÁNDOR, Á. OLÁH ZSUPOSNÉ \\ Debrecen University Centre for Agricultural and Applied Economic Sciences \\ Department of Agrochemistry and Soil Sciences, Debrecen \\ katai@agr.unideb.hu
}

\section{Introduction}

For preservation and sustainability the productivity of soil we have to take special regard to the sandy soils having unfavourable properties. These soils have very low colloid contents, their water management is extreme due to the weak structure with only transmission pores, and the nutrient management is also pour (HENZSEL, 2008). According to LAZÁNYI, (2003) the natural soil amendments for acidic sandy soils can arrange into three groups: 1. green manure and other organic matter, 2. farmyard manure and different composts, 3 . mining soil improving material originating from mining industry, e.g. alginite, bentonite, zeolite.

The bentonite is a rock containing clay minerals, mainly Smectites (PÁRTAI et al., 2006). The primary effect of bentonite is to improve the water holding capacity and moisture content of soil and through this property contribute to the stimulation of biological activity (SHIMMEL \& DARLEY, 1985; USMAN et al., 2005, LAZÁNYI 2005). When mix the bentonite with soil, increase the mineral nutrient content, the colloid content of soil, and with the higher colloid content decrease the leaching of different nutrients (NOBLE et al., 2000).

The zeolites is crystalline hydrous aluminiosilicates, the two main important mineral of it the Clinoptilolite and Mordenite tectosilicates (MÁTYÁS, 1979). In plant growing experiment where the zeolite was used as nutrient supply, decreased the acidity of soil, favourably influenced the micro-elements supply, (GHRAIR et al., 2008), moreover helped for plants in the water lifting, and improved water management of soil (PISAROVIC et al., 2003).

In a pot experiment the effect of increased dosages of bentonite and zeolite $\left[5 ; 10 ; 15 ; 20 \mathrm{~g} \mathrm{~kg} \mathrm{soil}^{-1}\right]$ was studied on some chemical properties, the microbial dynamic, the enzymological properties and on a testplant's biomass (Lolium perenne L.) of an acidic $\left(\mathrm{pH}_{\mathrm{H} 2 \mathrm{O}}=5.65\right)$ humic sandy soil [WRB: Lamellic Arenosol (Dystric)]. 


\section{Materials and Methods}

The pot experiment was set up in 2007 and 2008 in the Debrecen University, Department of Agrochemistry and Soil Science on acidic humic sandy soil. Every pot had $6 \mathrm{~kg}$ soil. Treatments were the same with the increased dosages of bentonite and zeolite (Table 1.). Five treatments, two amendments and three repetitions, it means 30 pots. The water content of treatments was in the same level, as the $70 \%$ of the maximum water capacity. The pots were sprinkled in every day to the same weigh. The testplant was perennial ryegrass; the sowing was in spring (14. 05. 2007; 21. 04. 2008).

As basic treatment $100 \mathrm{mg}$ nitrogen $-\mathrm{Ca}\left(\mathrm{NO}_{3}\right)_{2}$ solution $-100 \mathrm{mg} \mathrm{P}_{2} \mathrm{O}_{5}$ and $100 \mathrm{mg} \mathrm{K}_{2} \mathrm{O}$ solution of potassium dihydrogen orthophosphate and potassium sulphate to every one $\mathrm{kg}$ soil. Soil and plant samples were taken in the fourth the eighth week after the seeds sprouted. The grass was cut by scissors. After the second sampling the experiment was liquidated. The $\mathrm{pH}$ of soil was measured in suspension of distilled water and $\mathrm{M} \mathrm{KCl}\left[\mathrm{pH}_{(\mathrm{H} 2 \mathrm{O})} ; \mathrm{pH}_{(\mathrm{KCl})}\right]$ and the hydrolytic acidity (FILEP, 1995), besides nitrate nitrogen content and the level of nitrate mobilization (FELFÖLDY, 1987), further the ammonium lactateacetate soluble phosphate and potassium content of soil was determined (FILEP, 1995 cit. GEREI, 1970).

Among the microbiological parameters the total numbers of bacteria (in meat soup agar) the number of microscopic fungi (in peptone glucose agar) was determined by plate dilution method according to SZEGI, (1979). The number of aerobic cellulose decomposing and nitrifying bacteria was determined (POCHON \& TARDIEUX, 1962) with the MPN (Most Probable Number) method in liquid culture media. The further parameters were the soil respiration (WITKAMP, 1966. cit. SZEGI, 1979), the microbial biomass C (MBC) and the microbial biomass N (MBN) (JENKINSON \& POWLSON, 1976), the activities of saccharase enzyme (BERTRAND cit. SZEGI, 1979), and urease enzyme (KEMPERS cit. FILEP, 1995). The biomass of test plant also was measured in every sampling time. Statistical evaluation was done by SPSS 13.0 program.

Table 1.

Treatments and their designation in the tables (2007-2008)

\begin{tabular}{|l|c|c|}
\hline \multicolumn{1}{|c|}{$\begin{array}{c}\text { Treatments and } \\
\text { dosages }\end{array}$} & \multicolumn{2}{|c|}{$\begin{array}{c}\text { Dosages } \\
\mathrm{g} \mathrm{kg}^{-1}\end{array}$} \\
\hline & BENTONITE & ZEOLITE \\
\hline 1. Control & 0 & 0 \\
\hline 2. Little dose & 5 & 5 \\
\hline 3. Middle dose & 10 & 10 \\
\hline 4. Middle-large dose & 15 & 15 \\
\hline 5. Large dose & 20 & 20 \\
\hline
\end{tabular}




\section{Results and Discussion}

The results are discussed according to the average values of the two year of experiment.

By the effect of little dose of bentonite the soil $\mathrm{pH}_{\mathrm{H} 2 \mathrm{O}}$ increased significantly (Table 2). Regarding the treatments of zeolite similar tendency was observed, by the effect of little dose increased the $\mathrm{pH}_{\mathrm{H} 2 \mathrm{O}}$ of soil, but in this case the difference was not significant. Concerning the $\mathrm{pH}_{\mathrm{KCl}}$ the small doses of every two amendments increased this $\mathrm{pH}$, the small and middle doses of bentonite and the small dose of zeolite significantly. The $\mathrm{pH}_{\mathrm{KCl}}$ decreased in a little scale by the treatments of large doses.

The values of hydrolytic acidity generally decreased, especially in case of bentonite; concerning the little and middle doses the differences were significant.

Table 2.

Effect of treatments on the $\mathrm{pH}$ and the hydrolytic acidity (2007-2008. average values of two years)

\begin{tabular}{|c|c|c|c|c|c|c|}
\hline \multirow{2}{*}{$\begin{array}{c}\text { Treat } \\
\text { ments }\end{array}$} & \multicolumn{3}{|c|}{ BENTONITE } & \multicolumn{3}{c|}{ ZEOLITE } \\
\cline { 2 - 7 } & $\mathrm{pH}_{(\mathrm{H} 2 \mathrm{O})}$ & $\mathrm{pH}_{(\mathrm{KCl}}$ & $\begin{array}{c}\text { Hydrolytic } \\
\text { acidity }\end{array}$ & $\mathrm{pH}_{(\mathrm{H} 2 \mathrm{O})}$ & $\mathrm{pH}_{(\mathrm{KCl})}$ & $\begin{array}{c}\text { Hydrolytic } \\
\text { acidity }\end{array}$ \\
\hline 1 & 5.78 & 4.51 & 13.51 & 5.84 & 4.65 & 12.85 \\
\hline 2 & $\mathbf{6 . 0 7}$ & $\mathbf{5 . 0 3}$ & $\mathbf{1 2 . 0 4}$ & 6.09 & $\mathbf{4 . 9 6}$ & 12.31 \\
\hline 3 & 5.86 & $\mathbf{4 . 7 1}$ & $\mathbf{1 2 . 3 7}$ & 5.92 & 4.74 & 12.28 \\
\hline 4 & 5.74 & 4.47 & 12.64 & 5.69 & 4.74 & 12.25 \\
\hline 5 & 5.70 & 4.45 & 12.88 & 5.72 & 4.62 & 12.22 \\
\hline \multicolumn{2}{|c|}{ LSD $_{5 \%} 0.29$} & 0.25 & 0.95 & 0.43 & 0.22 & 0.67 \\
\hline
\end{tabular}

With reference to the macro-nutrients of soil some similar results could be observed. By the effect of little and middle doses of bentonite, (Table 3.) the nitrate nitrogen content of soil increased significantly (Treatments 2. and 3.), while in the treatments of the larger doses (4. and 5. treatments) decreased the $\mathrm{NO}_{3}-\mathrm{N}$ content, below the control pot. Regarding to zeolite, the little and middle doses of amendment increased the $\mathrm{NO}_{3}-\mathrm{N}$ content of soil, but this difference was not significant.

The easily available AL-phosphorus content of soil was increased by the effect of middle dose of bentonite. Regarding to the AL-soluble potassium, the little and middle doses of bentonite increased the easily available potassium of soil significantly. By the effect of zeolite, in every treatment both phosphorus and both potassium content of soil increased, in most cases significantly. It has to emphasize that the available potassium content respond to positively to the all doses of zeolite. 
Table 3.

Effect of treatments on the easily available nutrients of soil (2007-2008. average values of two years)

\begin{tabular}{|c|c|c|c|c|c|c|}
\hline \multirow[b]{2}{*}{ Treatments } & \multicolumn{3}{|c|}{ BENTONITE } & \multicolumn{3}{|c|}{ ZEOLITE } \\
\hline & 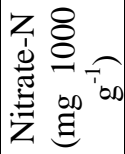 & 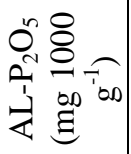 & 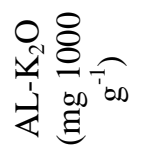 & 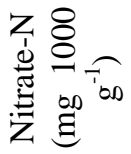 & 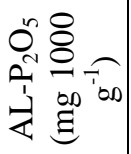 & 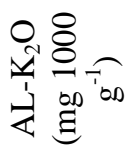 \\
\hline 1 & 3.82 & 92.47 & 240.42 & 4.01 & 97.34 & 231.09 \\
\hline 2 & 5.11 & 98.25 & 297.92 & 4.57 & 122.25 & 268.75 \\
\hline 3 & 5.21 & 111.83 & 275.67 & 4.28 & 107.67 & 255.00 \\
\hline 4 & 3.70 & 88.22 & 264.59 & 4.18 & 125.95 & 268.92 \\
\hline 5 & 3.24 & 87.78 & 248.75 & 3.33 & 115.50 & 270.84 \\
\hline $\mathrm{LSD}_{5 \%}$ & 1.04 & 7.41 & 25.63 & 1.04 & 12.51 & 21.43 \\
\hline
\end{tabular}

In order to get more information about the effects of two soil improving material, the dynamics of soil microorganisms and changes in their activity also was investigated (Table 4.).

Regarding the measured soil microbial parameters, first of all the total number of bacteria was determined. Among treatments of the two amendments the little and medium dosages proved to be very effective on bacteria number, in the mentioned treatments the differences were significant, moreover concerning bentonite the middle-large dose also resulted significant increase in bacteria number. The large doses did not result significant differences compare to control.

Evaluating the number of microscopic fungi, only the little dose of bentonite and middle dose of zeolite increased the number of fungi, in all other treatments decreased their number. The effect of large doses of amendment had depressive effect on soil microscopic fungi.

Among the physiological groups of bacteria the number of aerobic cellulose decomposing and nitrifying bacteria was measured. The number of cellulose decomposing bacteria increased significantly by the effect of little and middle treatments of bentonite. Regarding to zeolite, the effect of middle dose increased the bacteria number significantly. The number of bacteria decreased in the pots treated with large dosages of amendments.

The middle dosages of amendments increased the number of nitrifying bacteria, and the little dose of bentonite also proved to be effective. The large does of zeolite decreased - not significantly - the number of nitrifying bacteria. 
The similar tendency was experienced regarding to the nitrogen mobilization, where the little, middle and middle-large treatments of both natural amendments increased significantly the nitrogen mobilization.

Table 4

Effect of treatments on some microbiological properties of soil (2007-2008. average values of two years)

\begin{tabular}{|c|c|c|c|c|c|c|c|c|c|c|}
\hline \multicolumn{11}{|c|}{ BENTONITE } \\
\hline 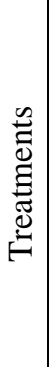 & 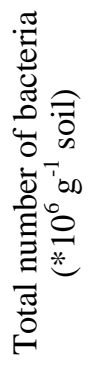 & 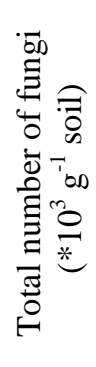 & 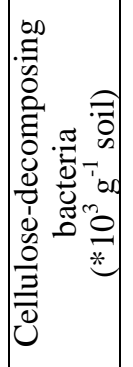 & 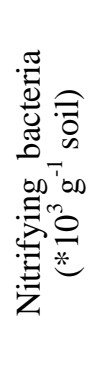 & 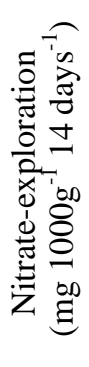 & 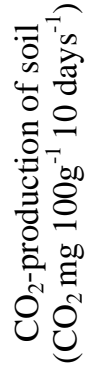 & 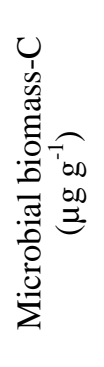 & 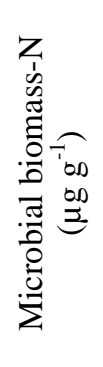 & 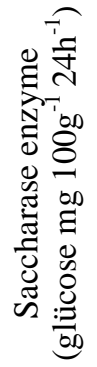 & 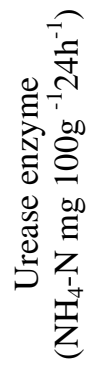 \\
\hline 1 & 2.39 & 56.58 & 2.70 & 1.33 & 5.52 & 4.38 & 153.3 & 11.71 & 4.77 & 69.14 \\
\hline 2 & 3.79 & 57.41 & 6.60 & 2.10 & 7.91 & 5.05 & 192.7 & $\mathbf{1 7 . 5 8}$ & 8.40 & 72.09 \\
\hline 3 & 4.70 & 54.92 & 7.40 & 2.78 & 7.31 & 5.63 & 178.7 & 22.66 & 10.71 & 74.31 \\
\hline 4 & 3.87 & 54.25 & 3.75 & 1.55 & 7.59 & 4.98 & 152.9 & 16.76 & 6.92 & 82.06 \\
\hline 5 & 2.84 & 50.75 & 1.90 & 1.35 & 4.77 & 4.09 & 148.0 & 12.72 & 4.30 & 81.35 \\
\hline \multicolumn{2}{|c|}{$\begin{array}{c}\text { LSD }_{\mathbf{5} \%} \\
1.36\end{array}$} & 8.93 & 1.59 & 0.76 & 1.06 & 0.66 & 10.55 & 2.31 & 1.78 & 7.27 \\
\hline \multicolumn{11}{|c|}{ ZEOLITE } \\
\hline 1 & 2.20 & 63.50 & 2.35 & 1.43 & 5.63 & 4.04 & 158.2 & 10.71 & 4.33 & 67.73 \\
\hline 2 & 4.09 & 62.91 & 2.58 & 1.78 & 8.12 & 4.82 & 199.7 & 15.66 & 6.23 & 72.63 \\
\hline 3 & 4.65 & 64.50 & 3.83 & 2.58 & 8.19 & 6.66 & 189.4 & 16.71 & 6.21 & 71.04 \\
\hline 4 & 2.54 & 60.58 & 2.68 & 1.32 & 7.55 & 4.91 & 174.6 & 17.69 & 4.52 & 73.04 \\
\hline 5 & 2.22 & 56.91 & 1.50 & 0.86 & 6.03 & 4.11 & 169.4 & 16.26 & 3.70 & 66.47 \\
\hline \multicolumn{2}{|c|}{$\begin{array}{c}\text { LSD }_{\mathbf{5} \%} \\
0.95\end{array}$} & 6.34 & 0.78 & 0.58 & 1.81 & 0.58 & 12.95 & 2.65 & 1.47 & 7.26 \\
\hline
\end{tabular}

With reference to $\mathrm{CO}_{2}$-production similar tendency was experienced as it was in case of nitrogen mobilization, the little, middle and middle-large dosages of amendments increased significantly the $\mathrm{CO}_{2}$-production.

The quantity of microbial biomass $\mathrm{C}$ increased significantly by the effect of little and middle dose of bentonite and also little, middle and middle-large dosages of zeolite.

The effect of amendment was more effective to the quantitative change of microbial biomass $\mathrm{N}$, because every dosage of bentonite and zeolite increased 
the quantity of MBN significantly, except one treatment, the large dose of bentonite, where the result did not reach the significant level.

Concerning the activity of saccharase enzyme significant increase was proved by the effect of little and middle dosages and also the middle-large dose of bentonite. The large dosages of amendment decreased the saccharase activity, but not significantly.

Regarding the urease enzyme activity, every treatment of bentonite was effective, especially the middle-large and large treatments, where the increases were significant. In the treatments of zeolite, the enzyme activity did not increase considerably.

At the end of experiment in 2007 and 2008, the weight of plant biomass was measured (Figure 1.)
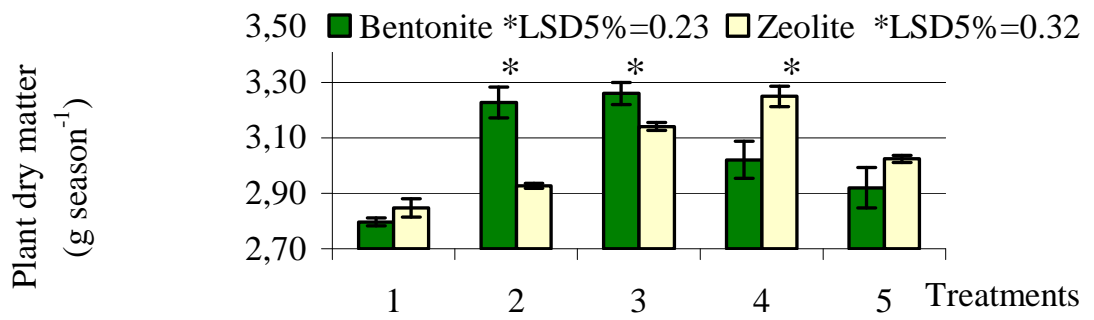

Figure 1.

Effect of bentonite and zeolite on the quantitative change of the test plant' biomass (2007-2008. average values of two years)

Every treatment of bentonite and zeolite increased the quantity of test plant biomass. Regarding bentonite treatments the dry matter of plant was between 2.80-3.26g in the average of two years, significant increase was measured by the little and middle dosages. In case of large dose treatment, the increase of dry matter was more moderate. Concerning zeolite treatments the dry matter of test plant was between $2.85-3.25 \mathrm{~g}$ in the average of two years, significant increase was measured by treatment of middle-large dose. Similar result was measured by the effect of large dose of zeolite, than in the bentonite, the increase of dry matter was moderate.

Correlation analyses was made to seek the relations among the different parameters (Pearson Correlations, HUZSVAI, 2004) at the base of the result of two years, (2007-2008) separate to bentonite and zeolite.

With reference to bentonite treatments the correlation between the hydrolytic acidity and aerobic cellulose decompose bacteria was negative $(\mathrm{r}=-0.660)$, on the other hand middle positive correlation was established between AL-soluble potassium and nitrifying bacteria $(\mathrm{r}=0.755)$. Moreover, the AL-soluble potassium was correlated with microbial biomass $\mathrm{C}(\mathrm{r}=0.773)$ and with 
microbial biomass $\mathrm{N}(\mathrm{r}=0.724)$, while the AL-soluble phosphorus was correlated with microbial biomass $\mathrm{C}$ positively $(\mathrm{r}=0.795)$. Also positive correlation was established between the $\mathrm{CO}_{2}$-production and number of aerobic cellulose decomposing bacteria $(\mathrm{r}=0.766)$, as well as the between the $\mathrm{CO}_{2^{-}}$ production and microbial biomass carbon $(\mathrm{r}=0.757)$. Regarding the plant biomass, only the nitrate-nitrogen content showed positive correlation with the biomass of test plant. Close correlation was established only between aerobic cellulose decomposing bacteria and saccharase enzyme activity ( $\mathrm{r}=0.864)$.

Regarding zeolite treatments, middle scale positive correlation was established between the $\mathrm{pH}_{\mathrm{KCl}}$ and easily available AL-soluble phosphorus $(\mathrm{r}=0.647)$, as well as between the $\mathrm{pH}_{\mathrm{KCl}}$ and total number of heterotrophic bacteria ( $\mathrm{r}=0.793$ ), besides it the AL-soluble phosphorus was correlated with the cellulose decomposing bacteria $(\mathrm{r}=0.696)$ positively. Negative correlation was established between the hydrolytic acidity and AL-soluble phosphorus content of soil $(\mathrm{r}=-0.696)$. Concerning the microbiological parameters, positive correlation was proved between the microbial biomass $\mathrm{C}$ and the activity of saccharase enzyme $(r=0.741)$, also positive correlation was established between the $\mathrm{CO}_{2}$-production and number of aerobic cellulose decomposing bacteria $(\mathrm{r}=0.600)$. Close correlation was established only between the number of nitrifying bacteria and microbial biomass $\mathrm{C}(\mathrm{r}=0.911)$.

The effectiveness of soil amelioration can be qualified with the increase of soil productivity. The effectiveness of different dosages of bentonite and zeolite as natural soil amendments in acidic sandy soil, can be qualify with changes in soil properties, in biological activity of soil and in the quantity of plant biomass; these parameters were investigated in our experiment.

By the effects of especially the little and middle dosages of all two soil amendments - bentonite and zeolite - increased the soil $\mathrm{pH}$, similar to the deduction of GHRAIR et al., (2008), and KÁTAI et. al., (2007). The little and middle dosages are equivalent with 15 , and $30 \mathrm{t} \mathrm{ha}^{-1}$ amendments. With the increase of $\mathrm{pH}$, decreased the hydrolytic acidity of soil, concerning bentonite, the result was significant.

The easily available AL-phosphorus and potassium content and nitrate mobilization give information about the nutrient supplying capability of soil. Even the little and middle dosages of bentonite and all dosages of zeolite increased the available AL-phosphorus and potassium content of acidic sandy soil, in some cases significantly.

These amendments having high cation exchange capacity, they increase the clay and nutrient content of soil, through these properties they decrease the leaching of nutrients, and create the balance of nutrient uptake (NOBLE et al., 2000; LAZÁNYI, 2003, SAVVAS et. al., 2004). Concerning the nitratenitrogen content of experiment, the little and middle dosages proved effective to increase it. 
By the effect of bentonite and zeolite treatments the biological activity of soil increased in the pot experiment through some different soil microbiological parameters, similar to the results of SHIMMEL \& DARLEY, (1985), or USMAN et al., (2005). Ten soil microbiological parameters were investigated in the experiment and among the treatments the little and middle dosages of bentonite and zeolite were the most efficient on the parameters examined. Positive effect of all dosages of zeolite and bentonite on microbial biomass nitrogen, the effect of zeolite on nitrate mobilization has to be emphasized. The number of microscopical fungi, the number of aerobic cellulose decomposing bacteria, the $\mathrm{CO}_{2}$-production, and saccharase enzyme activity were decreased by the effect of large dosages of the two amendments.

The quantity of test plant biomass increased in the bentonite and zeolite treatments. The little and middle dosages of bentonite and large dose of zeolite resulted significant increase in plant biomass.

\section{Conclusion}

The low $\mathrm{pH}$ is one of the limiting factors in soil productivity, especially if it associates with low colloid content, weak nutrient management and extreme water management of soils. The amelioration of these soils is urgent, and to test the new and perspective soil amendments is important research field.

At the bases of our research work it can be stated that the bentonite and zeolite as natural amendments suitable for the amelioration of the acidic $\left(\mathrm{pH}_{\mathrm{H} 2 \mathrm{O}}=5.65\right)$ humic sandy soil in Nyírség, Hungary through the favourable influence of chemical and microbiological properties of soil. Among the applied five different dosages the little and middle dosages, they equivalent with 15 and $30 \mathrm{t} \mathrm{ha}^{-1}$ dosages, influenced the soil properties most favourably. The effects of larger dosages than $30 \mathrm{t} \mathrm{ha}^{-1}$ on soil chemical and microbiological properties, was not unambiguous or positive.

\section{Summary}

In a pot experiment, the effect of increased dosages $\left[5 ; 10 ; 15 ; 20 \mathrm{~g} \mathrm{~kg} \mathrm{soil}^{-1}\right]$ of bentonite and zeolite was studied on some chemical properties and ten soil microbiological and enzymological properties of an acidic $\left(\mathrm{pH}_{\mathrm{H} 2 \mathrm{O}}=5.65\right)$ humic sandy soil [WRB: Lamellic Arenosol (Dystric)], as well as the biomass of perennial ryegrass as test plant (Lolium perenne $L$.).

The pot experiment was set up in 2007 and 2008 in the Debrecen University Department of Agrochemistry and Soil Science in three repetitions. The average results of two year's experiment can be summarized as follows: 
The $\mathrm{pH}$ increased by the effect of low and middle dosages of amendments. The bentonite treatments were more effective than the zeolite. With the increase of the $\mathrm{pH}$, the hydrolytic acidity - in case of the bentonite treatments significantly - decreased.

Concerning the easily available nutrient content of the soil, the little and middle dosages of amendments proved to be effective. The large dose of bentonite treatments reduced the nitrate- $\mathrm{N}$ content, the easily available phosphorus, and potassium content of soil; by zeolite treatments the high dose decreased the nitrate $-\mathrm{N}$ content of soil. The large dose of zeolite increased both phosphorus and both potassium content of soil, in most cases significantly.

Regarding the measured soil microbial parameters, the little and medium dosages of amendments proved to be most effective.

The bentonite and zeolite treatments increased the biomass of perennial ryegrass especially the low and medium dosages of bentonite and large dose of zeolite were significant.

According to the statistical analyses moderate and close correlation was found between the parameters studied.

In the treatments of bentonite, close correlation was established between the aerobic cellulose decomposing bacteria and saccharase enzyme activity $(\mathrm{r}=0.864)$ of soil. Concerning zeolite treatments, close correlation was established between the number of nitrifying bacteria and microbial biomass $\mathrm{C}$ $(\mathrm{r}=0.911)$ of soil.

Keywords: bentonite, zeolite, acidic humus sandy soil, soil features, dynamics of microbes, microbial activity, enzymes activity, plant biomass.

\section{References}

FELFÖLDY L., 1987. A biológiai vízminősítés. (4. Javított és bővített kiadás). Budapest. 172-174. p.

FILEP GY., 1995. Talajvizsgálat. (Egyetemi jegyzet) Debrecen, 32-56., 68-71; 93-96., $105-107 \mathrm{p}$.

GEREI L. (szerk.) 1970. Talajtani és agrokémiai vizsgálati módszerek. OMMI kiadvány. 19-17. p.

GHRAIR, A. - INGWERSEN, J. \& STRECK, T., 2008. Immobilization of heavy metals in soil using nanoparticles produced from zeolitic tuff. Eurosoil 2008. (Vienna-Bécs) August 25-29. Soil-Society-Environment. Book of Abstracts. Winfried E. H. Blum, Martin H. Gerzabek and Manfred Vodrazka (Eds.) University of Natural Resources and Applied Life Sciences (BOKU) 211-212. p.

HENZSEL I., 2008. Talajvédelem homoktalajon. In: Talajvédelem (Különszám). Talajtani Vándorgyülés, Nyíregyháza, május 28-29. Talajvédelmi Alapítvány, Bessenyei György Könyvkiadó. 89-94. p. 
HUZSVAI L., 2004: Biometriai módszerek az SPSS-ben, SPSS alkalmazások, DE MTK, Debrecen. (Kézirat). 75-77 p.

JENKINSON, D. S. \& POWLSON, D. S., 1976. The effect of biocidal treatments on metabolism in soil. A method for measuring soil biomass. Soil Biol. Biochem. 27/8, 209-213. p.

KÁTAI, J. -TÁLLAI, M. - LAZÁNYI, J. - LUKÁCSNÉ VERES, E. - SÁNDOR, ZS., 2007. The effect of bentonite on specific soil parameters and microbial characteristics of the carbon cycle. Joint international Conference on Long term Experiments. Published by DU. 247-254.p.

LAZÁNYI J. 2003. Bentonitos tufa jelentősége a homoktalajok javításában. Agrárgazdaság Vidékfejlesztés és Agrárinformatika az évezred küszöbén (AVA), DE ATC Debrecen, április 1-2. 4-8. p.

LAZÁNYI, J., 2005. Effects of bentonite on the water budget of sandy soil. Technologii de Cultura Pentru Grau Si Porumb Sympozion International. 7-8 iulie OradeaRomania 293-300.p.

MÁTYÁS E., 1979. A természetes zeolitok és zeolit tartalmú kőzetek földtani-teleptani jellemzése, különös tekintettel azok gyakorlati alkalmazás szempontjából fontos tulajdonságaira. Felhasználói szimpózium. Szerencs. 8-14.p.

NOBLE, A. D. - GILLMANN, G. P. \& RUAYSOONGNERN, S., 2000. A cation exchange index for assessing degradation of acid soil by further acidification under permanent agriculture in the tropics. European Journal of Soil Science. 51, 233-243. p.

PÁRTAY G. - RAJKAINÉ V. K. \& LUKÁCS A., 2006. Kálium- migráció vizsgálata káliföldpáttal kezelt gyökérközegben. Agrokémia és Talajtan. Vol. 55. No. 2. 395414. p.

PISAROVIC, A. - FILIPAN, T. \& TISMA, S., 2003. Application of zeolite based special substrates in agriculture-ecological and economical justification. Periodicum Biologorum 105 (3): 287-293. p.

POCHON, J. \& TARDIEUX, P., 1962. Techniques D' Analyse en Micobiologie du Sol. Collection „Technivues de Base”. Masson co. Paris. 102. p.

SAVVAS, D. - SAMANTOUROS, K. - PARALEMOS, D. - VLACHAKOS, G. STAMATAKIS, M. - VASSILATOS, C., 2004. Yield and nutrient status in the root environment of tomatoes (Licopersicon esculentum) grown on chemically active and inactive inorganic substrates. Acta Horticulturae 644: 377-383. p.

SCHIMMEL, S. M. \& DARLEY, W. M., 1985. Productivity and density of soil algae in an agricultural system. Ecology 66 (5) 1439-1447. p.

SZEGI J., 1979. Talajmikrobiológiai vizsgálati módszerek. Mezőgazdasági Kiadó, Budapest. 250-256. p.

USMAN, A. - KUZYAKOV, Y. \& STAHR, K., 2005. Effect of clay minerals on immobilization of heavy metals and microbial activity in a sewage sludgecontaminated soil. Journal of soils and sediments. Vol. 5. Iss. 4. 245-252. p.

WITKAMP, M., 1966. Decomposition of leaf litter in relation to environment microflora and microbial respiration. Ecology, 47. 194-201. p. 